\title{
YAHWE, TUHAN DALAM ALKITAB TEOLOGI PERJANJIAN LAMA BERNHARD LANG
}

\author{
ARIS MARGIANTO ${ }^{1}$
}

\section{Pendahuluan}

Berdasarkan kritikannya terhadap penelitian-penelitian sebelumnya, yang terutama lebih banyak menyibukkan diri dengan detail-detail, B. Lang mencoba untuk memaparkan sebuah gambaran yang baru dan hidup tentang Tuhan dalam Alkitab. Menurut pendapatnya, [Terj. Penulis] "hasil-hasil penelitian ini seringkali baru dan sangat berkesan, tetapi potret dari Tuhan Ibrani masih tetap saja dalam detail-detail yang tidak terstruktur, tanpa sebuah sistematika dalam kaitankaitan yang lebih besar dari detail-detail tersebut."2 Dari sana B. Lang menerapkan sebuah pendekatan baru bagi tujuannya, untuk merekonstruksikan sebuah paparan menyeluruh dari Tuhan dalam Alkitab. Dalam tulisan ini penulis hendak memaparkan metode yang digunakan oleh B. Lang dan hasil analisa dari karyanya. Selanjutnya, penulis hendak mengajukan kritik terhadap teologi Perjanjian Lama B. Lang.

\section{Pendekatan Teologi PL Bernhard Lang}

Dalam karyanya B. Lang menawarkan sebuah pendekatan baru yang didasarkan pada kenyataan, bahwa baik wujud dari Tuhan Ibrani maupun budaya Alkitab secara keseluruhan mempunyai sebuah hubungan yang sangat dekat dengan dunia Timur Dekat Kuno, khususnya Mesopotamia dan Mesir. Agama Israel dipahami sebagai „sebuah bentuk dari agama bersama dari Timur Dekat Kuno“. Selain itu teori ilmu budaya khususnya theori tiga fungsi dari Dumézil menunjukkan peran pentingnya bagi interpretasi sejarah agama.

Secara skematis Theori Dumézil tentang "Tiga Fungsi” dapat digambarkan sebagai berikut:

1 Dr.Aris Margianto merupakan dosen STT Abdiel.

2 Lang, Bernhard, Jahwe, der biblische Gott. Ein Porträt, München 2002, hal. 8. 


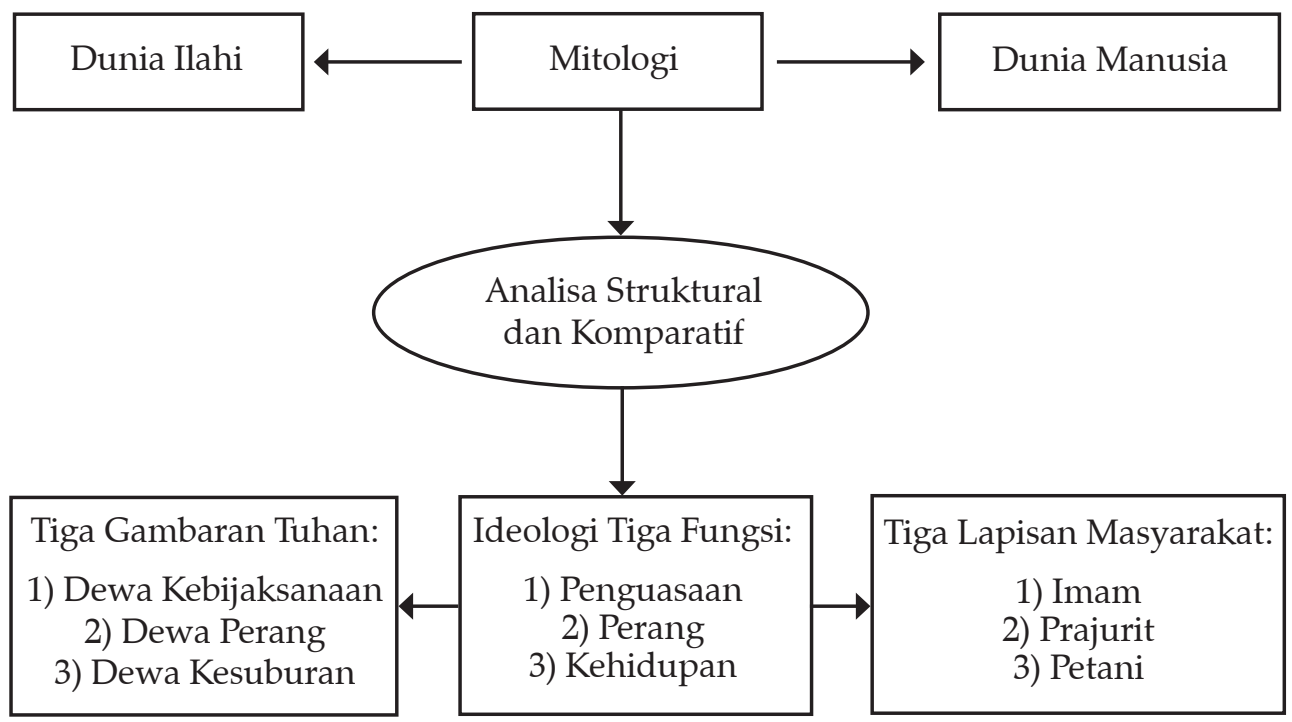

Dalam teorinya mitos-mitos dipandang sebagai sebuah konstruksi sosial. Di dalam mitos-mitos tersebut tercermin tatanan sosial dari dunia manusia. Apa yang berlaku bagi para dewa, berlaku juga sama seperti halnya bagi dunia manusia. Dumézil menganalisis mitos-mitos secara strukturalis dan mengembangkan sebuah metode baru untuk membandingkan terutama mitos-mitos Indo-Eropa. ${ }^{3}$

[Terj. Penulis],Mitologi baru yang bersifat membandingkan dari Dumézil tidak membandingkan fakta-fakta dan motif-motif terisolasi sendiri-sendiri secara atomistis, melainkan sistem-sistem kompleks (kelompok-kelompok para dewa [triad-triad], rantai-rantai dari gambarangambaran, mitos-mitos dan lain-lain) dan dengan demikian dapat mencapai kesimpulan-kesimpulan yang pasti dalam hal persesuaian-persesuaian."

Menurut B. Lang:

[Terj. Penulis],keberhasilan penemuan paling penting dari Dumézil adalah pada wilayah sejarah agama. Dia mengenali, bahwa juga para dewa dan keberadaan-keberadaan supranatural terorganisir menurut sebuah

3 Lih. Schmitt, R., Art. Dumézilische Dreifunktionentheorie, in Beck, Heinrich, u.a., (Hrg.), Reallexikon der Germanischen Altertumskunde, Band 6, Berlin 1986, hal. 277.

4 Ibid, S. 278-279. Tentang perkembangan teori Dumézil, C. Scott Littleton menulis dalam bukunya, The New Comparative Mythology: An Anthropological Assessment of the Theories of Georges Dumézil, Berkeley and Los Angeles 1966, hal. 43-142. Terdapat tiga fase perkembangan: die formative Phase (1924-1938), die Entwicklungsphase (1938-1949) und die fluorszierende Phase (1949 bis heute). 
prinsip yang dapat dibandingkan dengan prinsip tiga bagian. Tiga bagian itu sendiri menstrukturkan dunia manusia seperti halnya dunia para dewa. Dalam masyarakat manusia terwujud tiga komponen, yaitu para guru, prajurit dan petani; dalam agama terdapat dewa-dewa kebijaksanaan, dewa-dewa perang dan dewa-dewa kesuburan."

Meskipun menurut Dumézil penerapan teori dia sebenarnya terbatas pada budaya-budaya Indo-Eropa, tetapi B. Lang berpendapat, bahwa teori tersebut dapat juga diterapkan bagi Alkitab untuk menganalisa obyek penelitiannya, yaitu figur dari Tuhan Ibrani. Banyaknya kontak antara orang-orang IndoEropa dengan bangsa-bangsa lain, di mana warisan budaya telah berjalan saling bergantian di kedua arah, dan dasar-dasar archetipial yang dapat mudah dikenali dari tiga fungsi itu sebagai sebuah mode yang mendasar juga universal dari organisasi masyarakat, berlaku sebagai alasan untuk pendapatnya itu.

Dengan mengacu pada teori tiga fungsi dari Dumézil, B. Lang meneliti teks-teks Alkitab yang di dalamnya pengaruh-pengaruh yang bersumber dari Mesir dan Timur Dekat dapat ditelusuri. Dia memakai sumber-sumber dari teks-teks Perjanjian Lama dan Mitologi-mitologi, ikonografi dan ritual-ritual dari Mesir dan Timur Dekat.

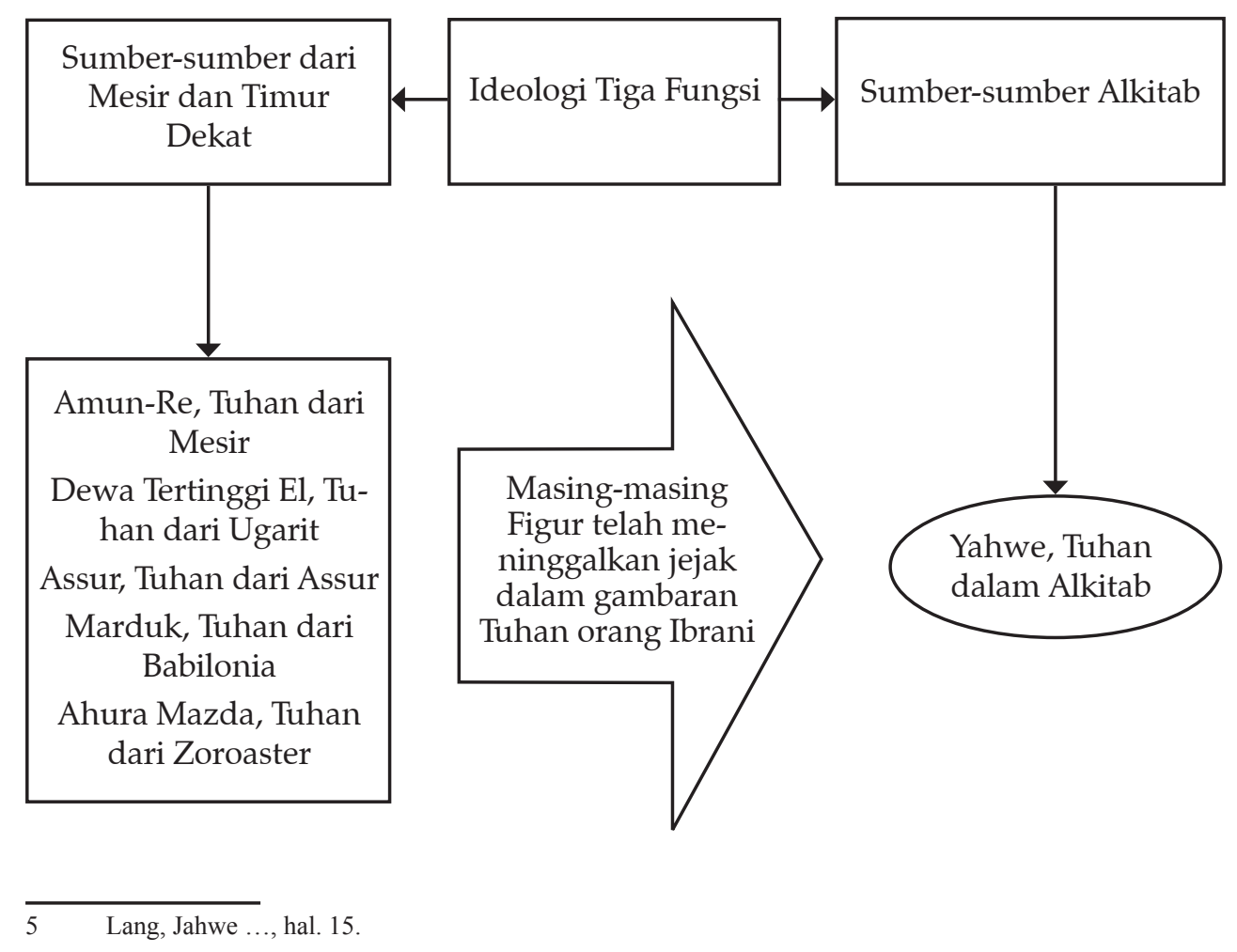


Dengan bantuan teori tiga fungsi sebagai sarana untuk menganalisis dan merancang bangun teologi Perjanjian Lamanya, B. Lang mengkategorisasikan figur dari Tuhan Ibrani ke dalam tiga, atau lima gambaran: Tuhan, Sang Penguasa Hikmat; Sang Penguasa Perang; Sang Penguasa Kehidupan, yang masih dapat dibagi lagi ke dalam tiga figur: Sang Penguasa Binatang; Sang Penguasa Individu; dan Sang Penguasa Tuaian. Figur-figur ini dapat juga dihubungkan dengan karya Allah yang dapat diringkaskan ke dalam tiga kata kerja ibrani jpv, [vy dan \$rb.

\section{Pokok-pokok Pikiran}

\section{III.1. Gambaran Tuhan sebagai Penguasa Hikmat}

Figur Tuhan Perjanjian Lama sebagai pemberi karunia pertama, hikmat, nampak menurut B. Lang dalam dua gambaran, yaitu yang archais dan postarchais. Masing-masing mempunyai asal-usul sendiri dan mewakili sebuah ideologi tertentu dari kelompok-kelompok masyarakat.

\section{III.1.1. Gambaran Archais}

Gambaran archais dari figur Sang Penguasa Hikmat terkait dengan fenomena hikmat esoterik yang memiliki akar-akar archais dan kuno. Dia berasal dari agama samanis yang kiranya dapat diterima sebagai budaya religius paling kuno.

Dalam masyarakat Israel terdapat tiga kelompok yang memiliki akses khusus ke dalam hikmat esoterik, atau kepada penguasa surga:

[Terj. Penulis] "nabi, yang dalam ekstase atau secara intuitif berhubungan dengan dewa-dewa; imam, yang melayani bermacam-macam teknik ramalan untuk menyampaikan kehendak para dewa; raja, yang dengan cara tertentu dipandang sebagai sama dengan tuhan. "6

Pencapaian pada hikmat ini terjadi melalui sebuah perjalanan ke sisi seberang yang akibatnya adalah sebuah transformasi ke dalam manusia baru.

B. Lang menunjukkan bahwa cerita Perjanjian Lama tentang perjalanan ke sisi seberang dari seorang raja, nabi dan imam berakar dalam kultus inisiasi samanis yang berpusat pada transformasi dan perjalanan ke sisi seberang. Cerita

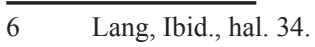


ini dapat dibandingkan dengan mitologi Mesopotamia seperti misalnya mitos tentang Raja Etana dan mitos-Adapa.

\section{III.1.2. Gambaran Postarchais}

Gambaran postarchais dari Tuhan sebagai Sang Penguasa Hikmat terkait dengan warisan budaya jaman perunggu, terutama hikmat pengetahuan politik dan hikmat pengetahuan para juru tulis. Dalam fragmen-fragmen Alkitab, Tuhan Israel tampil sebagai sosok bijaksana yang dapat dibandingkan dengan dewa El. El adalah dewa pencipta yang mengatur dunia dan yang mempunyai dewi sebagai pegawai dan penulis, bernama "Hokma“. Dalam mitologi penciptaan dunia tercermin "hikmat alam“ yang dikembangkan oleh para guru dari sekolah bagi para pegawai kerajaan. Para pegawai dalam istana kerajaan dituntut untuk menguasai pengetahuan-pengetahuan tentang tatanan dunia, karena harmoni antara tindakan profesional mereka dengan tatanan tersebut merupakan jaminan bagi hukum dan keadilan.

Karya lain dari dewa pencipta yang juga digambarkan sebagai dewa tertinggi yang bijaksana adalah pembagian bangsa-bangsa dibawah anak-anak ilahinya. Kitab Daniel memelihara mitologi politeis tentang dewa tertinggi yang bijaksana dan anak-anaknya. Dalam pandangan dari tradisi penobatan para dewa oleh dewa tertinggi terletak kedekatan pemikiran tentang Yahwe, Tuhan Israel. Inti pesan mimpi Daniel adalah bahwa dewa tertinggi memastikan bahwa kepada Israel diberikan perhatian khusus di surga.

Seni menulis tidak hanya memberi sumbangan bagi gambaran Tuhan sebagai pegawai dengan kegiatan administratifnya, melainkan juga sebagai pemberi hukum dan juru tulis. Gambaran ini merupakan sebuah pencerminan dunia manusia. Raja dengan dukungan dari para pegawainya bertanggung jawab terhadap tatanan masyarakat. Membaca dan menulis merupakan dasar kompetensi mereka untuk mempelajari ilmu hukum dan khususnya bagian yang terpenting darinya, yaitu hukum perjanjian, karena dalam kehidupan bisnis demikian juga privat di wilayah Mesopotamia keberadaan perjanjian memainkan peran penting. Seperti halnya para penguasa di wilayah Mesopotamia, para raja Israel dan Yehuda berlaku juga sebagai master yang bijaksana bagi para bawahannya, dan mereka juga mengandalkan para pegawainya yang terlatih.

Teologi perjanjian dalam Perjanjian Lama terkait dengan gambaran Tuhan sebagai pemberi hukum. Kitab Taurat muncul terutama sebagai sebuah kitab 
hukum, yang pusatnya adalah kumpulan-kumpulan hukum (demikian, khususnya dalam kitab Keluaran, Imamat dan Ulangan), yang di dalamnya tercermin budaya hukum dari Mesopotamia. Dalam kitabUlangan terdapat motifmotif yang sama dari perjanjian-perjanjian antara bangsa Asur dengan bangsabangsa yang ditaklukkan, yaitu: 1) Perkenalan diri dari pihak yang berbicara; 2) sebuah prolog historis dengan paparan tentang hubungan dari kedua belah pihak sampai sekarang ini; 3) sebuah katalog yang berisi kewajiban-kewajiban dari pihak-pihak dalam perjanjian; 4) sebuah klausul tentang pemeliharaan dan pembacaan secara berkala dari kesepakatan; pembacaan seharusnya dilakukan di setiap tahun ketujuh; 5) referensi tentang dewa atau dewa-dewa sebagai saksi; dan 6) berkat dan kutuk.

Tuhan, sang pemberi hukum, yang telah menyatakan dirinya pada bangsa Israel di gunung Sinai, telah mengikat perjanjian dengan umatNya. Selama Israel mengikuti hukum Tuhan dan khususnya memenuhi perintah utama tuntutan untuk hanya menyembah Yahwe saja sebagai Tuhan -, Tuhan akan memimpin umatNya dan memberikan perlindungan dan semua berkatnya bagi mereka. Kapan pemikiran semacam ini muncul di Israel? B. Lang memaparkan sebagai berikut:

[Terj. Penulis] „Penelitian setuju bahwa pemikiran tentang perjanjian antara Tuhan dengan umatNya dalam sejarah agama dalam Alkitab tidak tua. Pemikiran ini muncul pada akhir abad ke tujuh dalam gerakan-hanyaYahwe-saja, terdapat terutama dalam kitab Ulangan dan tulisan-tulisan lain yang dalam gaya bahasa dan warisan pemikirannya dekat dengan karya tersebut. Ide tentang ikatan perjanjian antara Tuhan dan umat diduga dikembangkan pada masa Raja Yosia yang pada tahun 611 s.M. melangsungkan reformasi religius yang terkenal. "7

\section{III.1.3. Penggantian Gambaran yang Archais dengan yang Postarchais}

Setelah penghancuran Yerusalem dan baitnya di tahun 586 s.M., ideologi tentang raja telah kehilangan artinya. Berlawanan dengan itu, arti dari kitab semakin meningkat. Tatanan perjanjian dipegang erat dalam sebuah buku. Tuntunan ilahi tidak lagi harus dicari melalui sebuah perjalanan ke sisi seberang, melainkan dianggap sebagai diatur dan tersedia dalam kitab suci.

$7 \quad$ Lang, Ibid., hal. 57. 
Kitab Ulangan mewakili sebuah pandangan yang jelas antisamanis, bahwa antara dunia ilahi dan manusia terdapat sebuah batas yang tidak dapat diseberangi. Perlawanan antara agama samanis dan deuteronomis begitu jelas dan tanpa kompromi. Ini adalah sebuah keputusan politik-keagamaan yang secara sadar menghapuskan semua sisa-sisa fenomena samanis, untuk memberikan theologi Alkitab profilnya sendiri yang postarchais. Berdasarkan kitab Ulangan kita dapat mengikuti proses kemunculan dari sebuah tipe agama baru, yaitu agama buku. Itu sebabnya kitab ini dapat diterima sebagai „pusat dari theologi Alkitab“ dan „intisari dari pemikiran Perjanjian Lama“.

\section{III.2. Gambaran Tuhan sebagai Penguasa Perang}

Di seluruh wilayah Timur Dekat, termasuk Israel, agama mendukung perang, karena Tuhan dipahami sebagai penguasa perang. Terdapat dua ideologi perang yang bersifat religius yang dapat dibedakan antara yang archais, yang menurutnya Tuhan mendukung pasukan dalam sebuah medan pertempuran, dan yang postarchais, yang menurutnya Tuhan membinasakan musuh tanpa campur tangan tindakan manusia.

\section{III.2.1. Gambaran Archais}

Di dunia kuno raja dipandang sebagai pemimpin bala tentara manusiawi dari dewa dan dewa digambarkan sebagai pejuang dan penguasa medan perang yang berkemenangan - deus militans dan deus victor. Sebagai prajurit, raja berperang atas perintah dewanya dan dipersyaratkan bahwa sang dewa berpihak pada raja dalam agresi militernya dan sebaliknya raja berperang di medan pertempuran bagi sang dewa.

Dewa ini tampil sebagai dewa negara yang pada saat yang sama dipandang sebagai dewa perang. Dewa perang ambil bagian dalam pertempuran: sebelum pertempuran dia menjanjikan kemenangan; selama pertempuran kehadiran dan pertolongan dari sang dewa dapat dilihat; dan setelah menang dalam beradu sang pemimpin pasukan memuji dewa perang sebagai pemenang yang sesungguhnya. Semua unsur ini-janji kemenangan ilahi, keberpihakan dalam pertempuran, pendirian sebuah tugu peringatan - terdapat dalam saga tentang perebutan kota Yeriko oleh orang-orang Israel, seperti diceritakan dalam kitab Yosua. Yahwe dipahami juga sebagai dewa perang.

Sebagai prajurit perang, raja mendapatkan senjata khusus yang berasal dari perbendaharaan dewa perang pada waktu dia naik takhta. Musuh-musuh dari dewa demikian juga Yahwe sekaligus juga musuh-musuh sang raja, dan raja itu akan 
mengalahkan musuh-musuhnya yang dipahami sebagai pihak yang terkait dengan naga samudera, dengan demikian perang yang dilangsungkan oleh sang raja pada saat yang sama mendapatkan dimensi-dimensi kosmis yang melampaui sesuatu yang dapat dilihat.

Mitos tentang pertempuran seorang prajurit ilahi melawan keberadaan yang merepresentasikan kekacaubalauan - dunia yang bersifat memusuhi dan tidak teratur - tersebar luas di wilayah Timur Dekat Kuno. Menurut B. Lang mitos ini tidak dapat dipahami sebagai pencerminan konflik di lingkungan alam, melainkan sebuah konflik dalam masyarakat manusia.

Tradisi Alkitab hanya sedikit atau bahkan sama sekali tidak tertarik dengan fenomena alam, cuaca, melainkan yang terutama pada peristiwa-peristiwa politik. Konflik antara prajurit ilahi dan lawan-lawannya yang bermacam-macam - Rahab, Tannin, Leviatan dan masih banyak lagi yang lainnya - terjadi bukan hanya jauh di masa lampau, melainkan dilihat sebagai konflik yang berlangsung terus-menerus. Alam, hidup manusia, masyarakat dan negara dipandang sebagai entitas yang rapuh dan instabil. Pertempuran antara prajurit ilahi dan lawannya tidak mempunyai akhir, karena setelah setiap kekalahan dalam pertempuran, kuasa-kuasa kegelapan memulihkan diri untuk membuat sebuah serangan baru, dengan demikian pertempuran dari para dewa akan dilangsungkan terus-menerus.

\section{III.2.2. Gambaran Postarchais}

\section{II.2.2.1. Tradisi Keluaran}

Perkembangan dari sebuah gambaran baru yang postarchais nampak pertama-tama dalam cerita saga tentang pelarian diri orang-orang Ibrani dari perbudakan di Mesir. Sajak Keluaran memalingkan pandangan dari gambaran prajurit ilahi; senjata, tindakan-tindakan untuk maju berperang, juga hasilhasil pencapaian bala tentara Israel tidak lagi disinggung. Dengannya sajak itu memproklamasikan sebuah perkembangan ideologi baru yang alurnya telah siap untuk dikenali, yaitu sebuah ideologi yang membawa pada penyingkiran peran serta manusia dalam peristiwa perang. Di sini musuh telah dikalahkan, toh bukan oleh tangan manusia. Gagasan itu telah dimulai untuk memancing perenungan terhadap fantasi-fantasi yang telah dikenal sebelumnya, dan pada akhirnya gagasan itu menguasai mentalitas apokaliptik.

\section{III.2.2.2. Tradisi Apokaliptik}

Dalam tradisi apokaliptik B. Lang menemukan dua tradisi yang berbeda, 
yaitu perang apokaliptik dan pengadilan apokaliptik. Dalam puisi dan prosa prophetik anonim diduga dari abad keenam atau kelima s.M. terdapat jejakjejak pertama yang tersedia jelas dari ide perang apokaliptik. Ciri-ciri perang apokaliptik dapat diringkaskan sebagai berikut:

Perang menguasai dunia; bangsa-bangsa berperang satu sama lain. Seringkali sebuah kekuasaan yang menguasai dunia dalam kedudukannya yang lebih tinggi terancam.

Orang-orang percaya (Yahudi dan Kristen) diancam atau kalau tidak dirugikan atau dirusakkan. Ada sebuah bahaya hidup.

Tuhan atau sosok yang diutus oleh Tuhan turun tangan demi orang-orang percaya dan menyelamatkan mereka dari bahaya kematian.

Motiv bersama yang ketiga - campur tangan Tuhan atau malaikat membentuk klimaks mitos apokaliptik dan kunci bagi pemahamannya.

Seperti pada perang apokaliptik, pengadilan apokaliptik juga merupakan kumpulan karya tentang gambaran-gambaran tertentu. Dia dapat dikarakteristikkan sebagai berikut:

Di surga pengadilan ilahi mengadakan sebuah sidang.

Pengadilan memvonis manusia-manusia dan kuasa-kuasa jahat yang dituntut dan mengijinkan supaya mereka dihukum dan dibinasakan.

Mereka yang baik, manusia-manusia yang setia pada kepercayaan agamanya, sebaliknya diberi upah, biasanya bahwa mereka setelah mati ditinggikan kepada malaikat-malaikat di surga.

Perbedaan antara kedua bentuk apokaliptik itu adalah bahwa perang apokaliptik merencanakan pembinasaan atau penghukuman kekal bagi musuh. Sebaliknya, dalam kerangka pengadilan apokaliptik bagaimanapun bisa terjadi sebuah pengampunan, keringanan hukuman dari vonis yang dijatuhkan dan belas kasihan.

Tetapi keduanya memiliki pesan yang sama bagi pembaca: penyelamatan orang-orang yang saleh dan orang-orang percaya. Dalam satu kasus penyelamatan diuraikan sebagai pembebasan dari ancaman hidup dalam perang atau penganiayaan, dalam kasus lain penyelamatan digambarkan sebagai 
pernyataan dari sebuah vonis hakim yang adil yang dengan baik membatalkan vonis tersebut. Dari kedua bentuk perang apokaliptik dan pengadilan apokaliptik yang tradisional tersebut sebuah drama besar dikomposisikan, yang dimulai dengan sebuah perang; kemudian diikuti oleh sebuah pengadilan, yang bagaimanapun belum digambarkan sebagai babak akhir. Melainkan perang dan pengadilan sekali lagi masih akan berulang.

\section{III.3. Gambaran Tuhan sebagai Penguasa Binatang}

Gambaran Tuhan sebagai Sang Penguasa Binatang tampil dengan dua wajah, yang positif dan negatif.

\section{III.3.1. Sisi Positif}

Setelah jaman berburu dan budaya gembala ingatan pada sosok ilahi sang penjaga dunia liar tetap hidup, karena manusia-manusia dari budaya kemudian tidak dapat meninggalkan jalur dari budaya sebelumnya tersebut. Tuhan dibayangkan sebagai deus ludens (Tuhan yang bermain). Dia adalah sang pemimpin tarian dan permainan dan duniaNya adalah dunia menakjubkan yang harmonis.

Orang-orang Israel masa Perjanjian Lama dan para keturunannya umat Yahudi awal tidak lagi hidup dalam budaya archais berburu dan mengumpulkan, melainkan bercocok tanam dan hidup sebagai gembala. Sudah pasti tidak ada lagi cara pencarian nafkah kuno yang menghubungkan diri dengan bentuk-bentuk kepercayaan masa lampau. Namun agama Israel yang lebih awal dan bersifat politheis tidak asing dengan kepercayaan pada Sang Penguasa Binatang.

Yahwe digambarkan juga sebagai Sang Penguasa Binatang. Tuhan adalah pencipta, pemilik dan pemelihara binatang. Kisah penciptaan dalam kitab Kejadian memberitakan tentang berkat Tuhan bagi binatang-binatang. Berkat berbicara pertama-tama tentang kesuburan; selain itu berkat mencakup juga janji untuk melindungi dan memelihara. Dalam Kitab Ayub teriakan binatang-binatang muda dipahami sebagai doa kepada Tuhan Sang Penguasa Binatang dan Yahwe digambarkan sebagai dues ludens, bahwa bagi Sang Penguasa Binatang, Leviathan itu adalah sebuah barang mainan. Masih tentang sisi positif, yaitu dunai harmonis dari Sang Penguasa Binatang, kitab Yesaya memaparkan keharmonisan antara manusia dan binatang.

\section{III.3.2. Sisi Negatif}

Sang Penguasa Binatang harus juga mengusahakan "mangsa“, makanan 
daging, pada manusia dan binatang. Oleh sebab itu manusia membutuhkan sebuah ijin dari para dewa untuk berburu dan membunuh binatang. Tuhan berkuasa atas binatang liar di hutan dan Dia memberikan kepada manusia sebuah hak khusus untuk membunuh binatang.

Binatang bukan hanya diburu, melainkan juga disembelih. Dalam hakekat korban terdapat hubungan antara penyembelihan dan ijin membunuh dari dewa. Kultus korban Israel sama sekali hanya dapat dipahami dalam keterkaitan itu. Segera setelah seekor binatang disembelih, ada bagian dari binatang tersebut bagian-bagian dalam tertentu - harus diambil tidak untuk konsumsi manusia dan dipersembahkan di atas altar Yahwe. Dengan dibakar di atas altar batu, jeroan itu dipersembahkan kepada Tuhan. Melalui tindakan korban, orang-orang Israel mengakui bahwa ijin untuk membunuh binatang bukankah hak yang berasal dari manusia sendiri, melainkan hak khusus dari Sang Penguasa Binatang. Berburu dan korban memelihara siklus kehidupan. Ia menghindarkan bukan saja sebuah kemacetan yang dapat membawa malapetaka bagi siklus kehidupan, melainkan juga mempertahankan siklus tersebut supaya tetap berjalan.

Manusia sebagai pemilik binatang merepresentasikan sebuah keserupaan gambar dari sang penguasa binatang ilahi. Bahwa Tuhan telah menciptakan manusia sebagai "gambar-Nya yang serupa", berlaku sebagai definisi religius mendasar dari keberadaan manusia. Bagaimana Tuhan berkuasa atas seluruh ciptaan, demikian manusia berkuasa atas dunia binatang. Manusia adalah mahkota penciptaan, penguasa atas binatang. Seperti sebuah duplikat yang diperkecil dari Sang Penguasa Binatang, manusia memiliki bagian dalam kekuasaan Tuhan atas ciptaan.

\section{III.3.3. Ideologi Sang Penguasa Binatang dalam Kitab Kejadian dan Ayub}

Peran Tuhan sebagai Penguasa Binatang telah diambil dan disusun secara sadar dalam dua penulisan yang berasal dari epos yang sama - dari masa sekitar 500 s.M.: dalam kitab Kejadian dan Ayub. Sang Penguasa Binatang mendominasi mitos penciptaan dalam Kejadian seperti halnya filsafat penderitaan yang dikembangkan dalam kitab Ayub.

Arti sepenuhnya dari pesan kitab Kejadian dapat dimengerti, jika pesan itu dipahami sebagai alternatif bagi sebuah program politis yang lain. Jalan ini memiliki tujuan untuk menegakkan kembali sebuah negara Israel yang kuat, sebuah kerajaan yang diperbaharui dan berkuasa, sebuah ideologi militer dan 
sebuah agama yang berfokus pada Tuhan Sang Penguasa Perang. Namun pada kenyataannya, sekitar tahun 500 s.M., tidak terbentuk sebuah negara judais yang baru, melainkan orang-orang Yahudi tetap saja hidup di bawah kekuasaan bangsa asing, di bawah tirani dan administrasi persia. Maka kitab Kejadian membela bukan untuk eksistensi historis melainkan alamiah, yang terumuskan dalam berkat dan perintah penciptaan dari Tuhan yang archais, Sang Penguasa Binatang. Setelah hilangnya eksistensi negara, penulis teringat kembali pada gambaran Tuhan yang archais dan dunia mitologis yang memberikan penghiburan dan keamanan. Itu saja yang memberinya keberanian untuk hidup di tanah Israel.

Motiv yang sama terdapat juga dalam kitab Ayub. Penyair kitab Ayub hidup di sebuah jaman yang di dalamnya ingatan pada peristiwa-peristiwa dari tahun 586 s.M. masih sangat hidup. Puisi kitab Ayub sebagai keseluruhan dapat dipahami sebagai sebuah perumpamaan sejarah Jehuda: sebuah bangsa yang kaya, telah kehilangan semua yang dia punya. Hidup dalam pembuangan di Babilonia dan diaspora, bermusuhan dengan Tuhan. Perenungan terhadap Tuhan, Sang Penguasa Binatang, baru membawa kembali berkat atas rakyat dan bangsa.

Baik kitab Ayub maupun Kejadian tidak menunjukkan ketertarikan pada tuhan yang politis dan historis. Pandangannya tidak terarah pada Tuhan, Sang Penguasa Perang yang membinasakan musuh-musuh dan memberikan kemenangan militer. Dikecewakan oleh kehidupan politik, mereka tertarik pada kenyataan-kenyataan yang mendasar saja - pada berkat, kesuburan, ternak dan keturunan. Apa yang mereka normatifkan adalah berkat ilahi.

\section{III.4. Potret Tuhan sebagai Sang Penguasa Individu}

Tuhan, Sang Penguasa Individu dipahami sebagai Tuhan personal. Di Israel dapat dibedakan dua bentuk agama personal: satu berasal dari kesalehan personal dari Mesir, yang lain mengikatkan diri pada spiritualitas Babilonia.

\section{III.4.1. Sumbangan dari Mesir: Patron Ilahi}

Bukti-bukti tradisional menunjukkan bahwa orang Mesir sebagai individu tahu bahwa dirinya terkait langsung dengan dewa dan merasa hidupnya berada di bawah bimbingan ilahi. Relasi antara dewa dan orang percaya sebagai individu, dari sisi manusia, ditentukan melalui pengabdian, kepercayaan, cinta, kepatuhan, doa dan korban atau melalui keikutsertaan pada upacara-upacara; 
dari sisi ilahi, melalui bimbingannya yang pasti, perlindungan dari bahaya dan cinta yang sama. Bahkan dapat dibayangkan sebuah relasi saling simpati satu sama lain antara dewa dan manusia sebagai seorang person, contohnya, jika seseorang mempersembahkan seluruh hidupnya pada dewa tertentu, dengan itu dia menempatkan dirinya di bawah perlindungan dewa tersebut. Tuhan dianggap sebagai patron/majikan seorang individu dan perlindungan dari patron/majikan manusia disingkirkan.

\section{III.4.2. Sumbangan dari Mesopotamia: Tuhan yang Bersifat Kebapakan dan Keibuan}

Kesalehan personal di Mesopotamia merepresentasikan dewa/dewi sebagai bapak yang memelihara atau ibu ilahi yang mengasihi. Pemazmur memberikan juga gambaran semacam itu, bahwa si anak emas dari sang dewa/dewi digambarkan sebagai seorang anak kecil dan sang dewa/dewi sebagai ibu atau perawat, atau sebagai seorang yang merawat bayi. Menurut B. Lang, kesalehan personal memperlihatkan sebuah bentuk yang membawa bersamanya regresi infantil yang menghubungkan manusia dewasa dengan masa kanakkanaknya dulu dan rasa aman terlindungi yang dirasakan. Kepuasan ,oral' dianggap sebagai landasan jiwa yang paling dalam dari kesalehan personal. Kecenderungan regresif yang diinternalisasikan pada sesuatu yang bersifat keibuan membentuk sebuah penyeimbang dalam kehidupan kaum laki-laki yang keras. Mekanisme kejiwaan yang sama atau mirip dapat menjelaskan keberhasilan yang sebelumnya belum ada dari gambaran Tuhan dalam wujud sebagai orang tua dalam kesalehan personal.

\section{III.4.3. Tuhan Personal dalam Kitab Ayub dan Perannya sebagai Tuhan Nasional}

Syaddai dipandang dalam kitab Ayub sebagai Tuhan personal. Syaddai telah menciptakan Ayub dan membawanya pada kemakmuran dan kebahagiaan. Elifas menggambarkan Syaddai sebgai Tuhan yang menghukum dan melukai, namun kemudian kembali membalut dan menyembuhkan. Selain itu dia memelihara anak kesayangannya dalam semua situasi sulit; Kelaparan dan perang tidak akan mampu menyakiti mereka, dan bagi mereka akan muncul keturunan yang banyak. Melalui penderitaan Ayub dan pemulihannya hendak diajarkan bahwa kebahagiaan bergantung pada Tuhan personal dan tidak dilihat sebagai hasil dari perbuatan baik dan kejujuran manusia. 
Tuhan personal dipahami dalam sejarah juga sebagai Tuhan nasional. Yahwe, Tuhan nasional Israel, memelihara umat secara keseluruhan sebagai Tuhan personal. Sebagai alasan, B. Lang menjelaskan latar belakang sosio-historis dari kitab Ayub, di samping bukti-bukti literer lainnya. Menurut dia:

[Terj. Penulis]"Kemungkinan kitab Ayub tidak ditulis untuk mendiskusikan nasib satu orang laki-laki yang mengeluhkan nasibnya pada Tuhan personalnya; melainkan dengan jelas lebih membahas tentang sebuah perumpamaan yang memperjelas nasib bangsa. Dibaca dari perspektif ini, kitab itu mencari untuk melukiskan kejatuhan dan pembangunan kembali Yehuda pada abad ke 6, di mana kehilangan atas kesehatan nasional dan kemakmuran secara umum diikuti oleh pemulihannya. Pesan khusus kitab Ayub adalah bahwa orang-orang Ibrani seperti Ayub dianggap bebas dari semua dosa dan sebagai konsekuensi tidak sepantasnya menerima nasibnya. Sementara kitab raja-raja dalam Alkitab memahami keruntuhan negara sebagai akibat dari ketidakpatuhan terhadap perintah pemujaanhanya-pada-Yahwe saja, kitab Ayub menegasikan setiap tanggung jawab umat. Tuhan, Sang Penguasa Hikmat yang memberikan hukum bertahan pada hukuman, namun toh Tuhan, Sang Penguasa Individu, yang bersifat keibuan menjamin restorasi bangsa dan semua yang baik yang dalam kehidupan di dunia ini dapat dibayangkan sepenuhnya."

\section{III.5. Potret Tuhan sebagai Sang Penguasa Tuaian}

Dalam teks Alkitab dapat dikenali dua gambaran Tuhan Penguasa Tuaian: sebuah gambaran yang menekankan pemberian alami berupa hujan dan tanah air yang subur, dan sebuah gambaran lain yang tertanam melalui pengalaman historis, yang menonjolkan pemberian tanah dan memproklamasikan perubahan ajaib negeri Palestina menjadi sebuah wilayah yang diberkati dengan sungai-sungai dan tuaian-tuaian yang begitu banyak. Kondisi geografis dan fenomena cuaca di wilayah yang dijuluki 'bulan sabit yang subur' menjadi dasar representasi Tuhan sebagai Sang Penguasa Tuaian.

$8 \quad$ Lang, Ibid., hal. 174. 


\section{III.5.1. Teologi Archais tentang Alam}

\section{III.5.1.1. Tuhan sebagai Tuhan atas Cuaca}

Hujan bagi orang Israel pada jaman dulu merupakan sebuah penampakan perbuatan dewa cuaca, atau dewa hujan, dan sama seperti gambaran Tuhan dalam mitologi Timur Dekat, terutama tentang dewa cuaca dari Siria, Baal, demikian juga Yahwe dipahami juga sebagai dewa cuaca. KehadiranNya termanifestasi melalui bencana alam yang sangat hebat disertai badai dan hujan badai yang hebat disertai guntur, halilintar dan angin kencang. Selain itu dipercayai bahwa bencana alam terutama kekeringan disebabkan oleh perilaku salah umat karena tidak memegang perintah Yahwe.

Pada jaman Alkitab ada juga ritual-ritual untuk mengirimkan hujan. Menurut gambaran kuno, tindakan-tindakan magis semacam itu bukan hanya merepresentasikan sebuah gema yang darinya apa yang terjadi di alam ini tidak bergantung pada manusia; lebih lagi ia dilaksanakan dengan keyakinan bahwa tindakan-tindakan kultis mendukung dan menopang siklus kosmis. Tanpa tindakan-tindakan ritual yang benar, hujan akan tertunda atau bahkan sama sekali tidak datang. Tetapi tanpa hujan kiranya pertanian mustahil dan hidup manusia seperti halnya binatang terancam.

\section{III.5.1.2. Tuhan yang Memberkati dan Mengutuk Tanah Pertanian}

Hanya melalui berkat (beracha) Tuhan kiranya tanah pertanian dapat menghasilkan buah. Berkat ilahi, kekuatan yang penuh rahasia untuk berkembang biak dan bertumbuh, akan memberikan pertama-tama binatang-binatang betina dan ibu-ibu manusia, dan kesuburan mereka merepresentasikan contoh yang baik setiap berkat yang juga dapat diteruskan bagi tanah pertanian.

Duacirikarakteristik pemaknaan Alkitabtentang berkatadalah, menurut Westermann, universalitas dan ketidakmenonjolan. Meskipun terutama memberi kepada Israel, berkat berlaku bagi semua bentuk kehidupan dan semua manusia, di dalam maupun di luar Israel. Tindakan Tuhan yang memberkati secara diam-diam sesuai dengan, menurut B. Lang, gambaran Tuhan sebagai Penguasa atas fungsi yang ketiga. Tetapi berkat Tuhan sebagai Penguasa atas fungsi yang pertama dan kedua memiliki ciri karakteristik lain. Tuhan bertindakan dengan cara yang menarik perhatian dan tidak dalam ketersembunyian. Tindakan-Nya begitu sangat terbatas dan tidak universal. 
Menurut pengertian Ibrani, Tuhan adalah sumber dari semua berkat, tetapi karena kesulitan-kesulitan nyata pada pekerjaan pertanian, terutama penanaman gandum, maka orang-orang Ibrani menyebut tanah sebagai "terkutuk". Penanaman gandum membangkitkan ingatan-ingatan pada pengusiran dari surga - di seberang lain dari Eden, manusia harus makan roti dengan berpeluh di hadapan-Nya.

\section{III.5.2. Theologi Postarchais dari Pengalaman Historis}

Kehilangan tanah menimbulkan bukan hanya sebuah ajaran tentang Palestina sebagai tanah yang Tuhan berikan bagi umat; kehilangan itu pada saat yang sama membawa pada gambaran-gambaran fantastik yang beragam yang berpuncak pada penantian bagi produktivitas tanah. Tanah Palestina digambarkan sebagai surga.

\section{III.5.2.1. Tanah sebagai Milik Tuhan dan Pemberian Ilahi}

Ancaman Asyur dan praktik pembuangan mengubah gambaran Israel tentang hubungan dengan Yahwe. Sama seperti orang-orang Asyur yang memahami sang dewa negara, Assur, sebagai pemilik wilayah bangsa mereka, demikian juga orang-orang Ibrani memahami Tuhan nasional mereka sebagai Tuhan yang telah memilih mereka dan menetapkan tanah itu bagi mereka; kepemilikan tanah mereka karena Tuhan. Oleh sebab itu pengalaman historis pembuangan diinterpretasikan sebagai akibat dosa bangsa bahwa oleh dosa mereka tanah itu telah tercemar. Tetapi Yahwe akan memurnikan kembali umatNya dan juga tanah-Nya yang tercemar. Tuhan akan berbelas kasih pada umatNya dan mengumpulkan mereka dari antara bangsa-bangsa.

\section{III.5.2.2. Perubahan Palestina menjadi sebuah Tanah dengan Sungai-sungai yang Kaya Air}

Pengalaman historis, hidup di Babilonia, menyebabkan kemunculan penantian utopis perubahan Palestina menjadi sebuah tanah yang kaya air. Menurut bukti-bukti tulisan keil dari abad ke 5 s.M., sebagian orang-orang Yehuda yang hidup di Babilonia bekerja sebagai pengawas kanal dan ahli irigasi; yang lainnya memperbaiki bendungan-bendungan kanal atau mengoperasikan pengairan pertanian. Yahwe digambarkan sebagai dewa air seperti Ea, dewa Babilonia. Yahwe telah memberi hadiah air tawah bagi kota Palestina. 
Apakah digambarkan sebagai dewa cuaca, penguasa air tawar atau pemiliki ilahi tanah, Yahwe Nampak selalu sebagai Tuhan atas tuaian, sebagai dewa kesuburan agraris yang berkat-Nya memungkinkan hidup manusia. Tanpa Tuhan, manusia tidak dapat menyelenggarakan hidup. Dalam hidup sehari-hari nampak bagi orang-orang Ibrani kekayaan dan kesehatan sebagai akibat yang sudah semestinya dari perbuatan dan pembiaran tertentu; dipahami secara religius, semua itu Nampak bagi mereka sebagai hadiah Tuhan. Kebahagiaan sendiri tidak lain ada dalam tindakan berhubungan dengan Tuhan dan hidup yang baik.

\section{Penutup}

Rancang bangun Teologi PL Bernhard Lang sangat menarik karena dia menggunakan pendekatan teori tiga fungsi yang digunakan oleh Dumézil untuk menganalisa kisah Mahabharata. Kisah Mahabharata sendiri, dengan tokoh utamanya lima bersaudara yang disebut sebagai Pandawa, bukanlah kisah yang asing bagi masyarakat Indonesia, khususnya Jawa. Dengan demikian, bagi mereka yang memiliki ketertarikan terhadap teologi kontekstual, Teologi PL Bernhard Lang dapat menjadi sebuah pijakan teologis bagi pengembangan upaya kontekstualisasi teologis dalam perjumpaannya dengan budaya.

\section{SUMBER BUKU:}

Lang, Bernhard, Jahwe, der biblische Gott. Ein Porträt, München 2002 